\title{
Vitreous leptin levels in retinal disease
}

\begin{abstract}
Background/aims The purpose of this study was to investigate the relationship between vitreous leptin levels and retinal diseases. Methods Levels of vitreous leptin were evaluated in proliferative diabetic retinopathy (PDR) and a variety of other retinopathies including: macular disease, neovascular maculopathies, primary retinal detachments, and vascular occlusive disease.

Results In patients with PDR $(N=7)$, the average vitreous level of leptin $(37.4 \mathrm{ng} / \mathrm{ml})$ was significantly higher than that in patients with PVR ( $<1.0 \mathrm{ng} / \mathrm{ml}, P<0.05)$. Vitreous leptin level in patients with PVR or macular disease $(N=18)$, with or without diabetes, was not significantly different from the control subjects who had retinal detachment only $(N=7)$. Conclusion The results show that the leptin level in vitreous taps is elevated in PDR. We suggest that leptin plays an active role in PDR. Eye (2006) 20, 801-804. doi:10.1038/sj.eye.6702011; published online 22 July 2005
\end{abstract}

Keywords: proliferative diabetic retinopathy; leptin; vitreous; enzyme-linked; Immunoabsorbent assays (ELISA)

\section{Introduction}

Retinal neovascularization is driven by a variety of angiogenic factors such as vascular endothelial growth factor (VEGF), insulin-like growth factor I (IGF-I), fibroblast growth factor (FGF), platelet-derived growth factor (PDGF), interleukins, and transforming growth factor $\beta$ (TGF- $\beta$ ). In addition to these well-known factors, a number of novel angiogenic proteins have recently been described. ${ }^{1-5}$

Leptin, an antiobesity hormone, is a 167 aminoacid protein synthesized in the pituitary gland, adipose tissue, and fibroblasts in the setting of high intracellular triglycerides. Serum leptin concentrations are proportional to the body's adipose mass. Leptin induces lipid metabolism, energy use, and satiety. Receptors for leptin have been identified on endothelial cells, fibroblasts,
D Maberley, JZ Cui and JA Matsubara

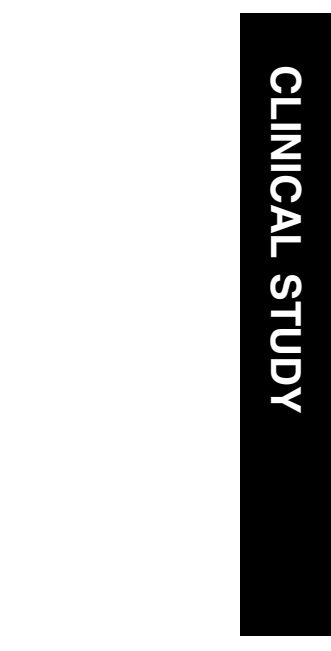

and in the retinal pigment epithelium. Recent studies have shown leptin to act as an angiogenic factor in vivo and can cause endothelial cells to proliferate and migrate. ${ }^{6}$ It is also found in higher concentrations in the plasma of individuals with hypertensive and diabetic retinopathy. ${ }^{6,9}$ Leptin levels in blood serum and vitreous have been correlated with neovascular eye diseases such as proliferative diabetic retinopathy.,11

Proliferative diabetic retinopathy (PDR) remains one of the major causes of acquired blindness in developed nations. Abnormal angiogenesis, the hallmark of PDR, leads to severe vision loss through secondary vitreous haemorrhage and/or vascular fibrosis with tractional retinal detachment. Factors and cytokines thought to play a role in the pathophysiology of PDR include: VEGF, acidic and basic FGF, TGF- $\alpha$ and TGF- $\beta$, and interleukins. Vitreous leptin levels in diabetic retinopathy have been shown to be elevated in patients with proliferative diabetic retinopathy. ${ }^{8}$ This same study also demonstrated elevated levels of leptin in the vitreous of subjects with primary retinal detachment. These findings were of interest to us given the lack of an obvious biologic mechanism that would explain the expression of leptin in both conditions.

Our primary goal for the present study was to evaluate vitreous leptin levels in a variety of retinal conditions.

\section{Patients and methods}

The purpose of this study was to investigate the relationship between vitreous leptin levels and retinal diseases. Ethical approval was obtained prior to the initiation of this project from the Vancouver Hospital and University of British Columbia's Institutional Review Board. The UBC CREB policies comply with the Tri Council Policy and the Good Clinical Practice Guidelines, which have their origins in the ethical principles in the Declaration of Helsinki. Written informed consent was obtained from patients. Levels of vitreous leptin were evaluated in a variety of retinopathies including: proliferative diabetic retinopathy
Department of Ophthalmology and Visual Sciences, University of British Columbia, Vancouver, BC, Canada

Correspondence: D Maberley, 2550 Willow St., Vancouver, BC, Canada V5Z 3N9

Tel: + 604875 4599;

Fax: + 6048754699

E-mail: crtg_vancouver@ hotmail.com

Received: 5 April 2005 Accepted: 27 May 2005 Published online: 22 July 2005 
$(N=7)$, macular disease $(N=10$, macular holes, epiretinal membranes), neovascular maculopathies $(N=2$, age-related macular degeneration, pseudoxanthoma elasticum with angioid streaks), primary retinal detachments $(N=7)$, and retinal detachment with PVR $(N=6)$, (see Table 1$)$. All subjects underwent a standard three-port vitrectomy, with a core sample of vitreous $(1.0-1.5 \mathrm{ml})$ taken prior to initiating the pars plana infusion. The undiluted vitreous samples were immediately frozen and stored at $-20^{\circ} \mathrm{C}$.

Immunoreactive levels of leptin were determined by enzyme-linked immunoabsorbent assays (ELISA Cayman Chemical, MI, USA). (ELISA: Range 1-50 ng/ml) Duplicate assays were performed on all samples.

Table 1 Leptin levels in the vary retinal disease processes

\begin{tabular}{|c|c|c|c|c|}
\hline $\begin{array}{l}\text { Case/sex/ } \\
\text { age (year) }\end{array}$ & Diagnosis & Past ocular history & Past medical history & $\begin{array}{l}\text { Vitreous } \\
\text { leptin level } \\
(\mathrm{ng} / \mathrm{ml})\end{array}$ \\
\hline
\end{tabular}

Primary rhegmatogenous retinal detachment $(N=7)$

\begin{tabular}{|c|c|c|c|}
\hline $1 / \mathrm{M} / 68$ & $\begin{array}{l}\text { Rhegmatogenous retinal } \\
\text { detachment reoperation }\end{array}$ & Failed pneumatic retinopexy & None \\
\hline 2/F/59 & Primary RD & 6 months post Yag capsulotomy & Asthma, on budesonide \\
\hline $3 / F / 67$ & $\begin{array}{l}\text { Rhegmatogenous retinal } \\
\text { detachment reoperation }\end{array}$ & Failed pneumatic retinopexy & $\begin{array}{l}\text { Hypothyroidism, on levothyroxine } \\
\text { sodium }\end{array}$ \\
\hline $4 / \mathrm{F} / 67$ & $\begin{array}{l}\text { Rhegmatogenous retinal } \\
\text { detachment }\end{array}$ & Cataract surgery 4 months prior & $\begin{array}{l}\text { Type II Diabetes (DM), diet controlled; } \\
\text { Hypertension, on hydrochlorothiazide; } \\
\text { Hypercholesteraemia, on lovastatin }\end{array}$ \\
\hline $5 / \mathrm{M} / 45$ & $\begin{array}{l}\text { Rhegmatogenous retinal } \\
\text { detachment }\end{array}$ & Myopia over -6 D & None \\
\hline $6 / \mathrm{M} / 62$ & $\begin{array}{l}\text { Rhegmatogenous retinal } \\
\text { detachment }\end{array}$ & Myopia over -6 D & None \\
\hline $7 / F / 77$ & $\begin{array}{l}\text { Rhegmatogenous retinal } \\
\text { detachment }\end{array}$ & Post cataract surgery 6 years & $\begin{array}{l}\text { Hypertension, on lisinopril and } \\
\text { hydrochlorothiazide }\end{array}$ \\
\hline
\end{tabular}

$<1$

Retinal detachment with proliferative vitreo-retinopathy $(N=6)$

8/M/54 Grade C2 PVR

9/M/46 Grade C1 PVR

10/F/66 Grade C1 PVR

11/F/52 Grade C2 PVR

12/M/21 Grade C3 PVR

13/M/62 Grade D PVR

Failed scleral buckle

Failed scleral buckle

Myopia over $-6 \mathrm{D}$

Myopia over $-6 \mathrm{D}$

Globe laceration with secondary

giant retinal tear and PVR

Prior cataract surgery

None

None

Hypercholesteraemia, on lovastatin

Hypertension, on $\beta$-blocker

None

None

$<1$

Postcataract surgery 6 months

Postcataract surgery 19 months

$14 / \mathrm{M} / 86 \quad$ Epiretinal membrane

15/F/69 Epiretinal membrane

16/F/70 Subretinal hemorrhage from neovascular age-related macular degeneration

17/M/48 Choroidal neovascular membrane secondary to pseudoxanthoma elasticum

18/F/57 Epiretinal membrane

19/F/66 Macular hole

Previous PDT in other eye

Carotid stenosis

Atrial fibrillation, on ASA and digoxin

Diffuse angioid streaks

None

Myopia over $-6 \mathrm{D}$

Previous cataract extraction in

Hypercholesteraemia, on atorvastatin

None affected eye

20/M/64 Tractional macular detachment

None

Asthma, on inhalers

None

Myopia over $-6 \mathrm{D}$

None

No diabetic retinopathy in either eye

No diabetic retinopathy in either eye. Cataract surgery 9 months prior
$<1$

$<1$

$<1$

$<1$

$<1$

$<1$

$<1$

$<1$

$<1$

$<1$

1.05

$<1$

$<1$

1.2

$<1$

$<1$

$<$

$<1$

1

1

.2

$<1$

$<1$

$<1$

$<1$

$<1$

$<1$ 
Table 1 (Continued)

\begin{tabular}{|c|c|c|c|c|}
\hline $\begin{array}{l}\text { Case/sex/ } \\
\text { age (year) }\end{array}$ & Diagnosis & Past ocular history & Past medical history & $\begin{array}{l}\text { Vitreous } \\
\text { leptin level } \\
(n g / m l)\end{array}$ \\
\hline \multicolumn{5}{|c|}{ Proliferative diabetic retinopathy $(N=7)$} \\
\hline $26 / \mathrm{F} / 66$ & $\begin{array}{l}\text { Proliferative diabetic retinopathy } \\
\text { with vitreous hemorrhage }\end{array}$ & $\begin{array}{l}\text { No prior pan-retinal laser. } \\
\text { Proliferation also present in } \\
\text { other eye }\end{array}$ & $\begin{array}{l}\text { Type II DM for } 16 \text { years, on insulin and } \\
\text { oral hypoglycemic; Below knee } \\
\text { amputation }\end{array}$ & 12 \\
\hline $27 / F / 56$ & $\begin{array}{l}\text { Proliferative diabetic retinopathy } \\
\text { with a sub-hyaloidal } \\
\text { haemorrhage. No haemorrhage } \\
\text { break through into vitreous }\end{array}$ & $\begin{array}{l}\text { Prior laser in study eye. } \\
\text { Other eye, moderate } \\
\text { nonproliferative disease. } \\
\text { Primary open angle glaucoma }\end{array}$ & $\begin{array}{l}\text { Type I DM for } 32 \text { years, on insulin; } \\
\text { Hypertension, on ramipril }\end{array}$ & 1.1 \\
\hline $28 / F / 55$ & $\begin{array}{l}\text { Proliferative diabetic retinopathy } \\
\text { with diffuse vitreous } \\
\text { haemorrhage }\end{array}$ & $\begin{array}{l}\text { Other eye, proliferative } \\
\text { diabetic retinopathy. } \\
\text { No previous laser }\end{array}$ & $\begin{array}{l}\text { Type II DM for } 10 \text { years, on oral } \\
\text { hypoglycemics; Hypertension, on } \\
\text { losartan potassium }\end{array}$ & 31.4 \\
\hline $29 / F / 56$ & $\begin{array}{l}\text { Proliferative diabetic retinopathy } \\
\text { with diffuse vitreous } \\
\text { haemorrhage }\end{array}$ & Prior laser OU & $\begin{array}{l}\text { Type II DM for } 25 \text { years, on oral } \\
\text { hypoglycemics; Asthma, on puffers }\end{array}$ & 42.5 \\
\hline $30 / \mathrm{M} / 53$ & $\begin{array}{l}\text { No active proliferative diabetic } \\
\text { retinopathy, but recurrent chronic } \\
\text { vitreous haemorrhages secondary } \\
\text { to vitreous traction on a small } \\
\text { elevated retinal venous loop }\end{array}$ & $\begin{array}{l}\text { Prior laser OU for proliferative } \\
\text { disease, } 10 \text { years before } \\
\text { haemorrhage began }\end{array}$ & Type I DM for 37 years, on insulin & $<1$ \\
\hline $31 / \mathrm{M} / 55$ & $\begin{array}{l}\text { Active, and incompletely treated, } \\
\text { proliferative diabetic retinopathy }\end{array}$ & $\begin{array}{l}\text { First laser } 3 \text { months } \\
\text { preoperatively. Primary } \\
\text { open-angle glaucoma }\end{array}$ & Type II DM for 8 years, on insulin & $>50$ \\
\hline $32 / F / 88$ & $\begin{array}{l}\text { Proliferative diabetic retinopathy } \\
\text { with bilateral vitreous } \\
\text { haemorrhages }\end{array}$ & No prior laser & Type II DM for 17 years, on insulin & $>50$ \\
\hline
\end{tabular}

\section{Results}

A total of 32 samples of vitreous were taken from 32 subjects. Seven eyes had proliferative diabetic retinopathy, 12 eyes had structural macular pathology (macular holes, epiretinal membranes, vitreo-macular traction syndrome, and submacular choroidal neovascularization), six had proliferative vitreoretinopathy (full range of grades represented), seven had primary rhegmatogenous retinal detachments (see Table 1).

Of the 12 individuals with structural macular pathology, two had type II diabetes, but none of these individuals had retinopathy of greater than ETDRS grade 43. Leptin levels for all of the vitreous samples are presented in Table 1 . The only study group that had elevated leptin levels beyond $1.2 \mathrm{ng} / \mathrm{ml}$ was the group with proliferative diabetic retinopathy. Two individuals who did not have PDR had leptin levels of 1.05 and 1.2; the former had a chronic total retinal detachment and the latter a massive subretinal haemorrhage secondary to age-related macular degeneration. No individuals with primary rhegmatogenous retinal detachment or structural macular pathology (diabetic or otherwise) had a vitreous leptin level above $1.00 \mathrm{mg} / \mathrm{ml}$. One individual with diabetic retinopathy and a vitreous haemorrhage had a vitreous leptin level of $<1.00 \mathrm{ng} / \mathrm{ml}$. This person was thought to have proliferative diabetic retinopathy preoperatively; however, intraoperatively it was noted that a single focus of vitreous traction on a venous loop was the underlying pathologic mechanism that was responsible for the haemorrhage.

\section{Discussion}

Elevated vitreous leptin levels were found only in eyes with proliferative diabetic retinopathy that had some degree of recent vitreous haemorrhage. All other retinal conditions did not demonstrate significant vitreous leptin levels.

Two prior studies have evaluated vitreous leptin levels in retinal disease; the results were conflicting. In Gariano's et $a l^{7}$ paper from 2000, elevated vitreous leptin levels were detected in the vitreous humor of human subjects with proliferative diabetic retinopathy and retinal detachment. A subsequent paper in 2004 did not demonstrate any association between vitreous leptin levels and proliferative diabetic retinopathy. ${ }^{10}$

Our results corroborate the findings associated with proliferative diabetic retinopathy in Gariano's study, but are divergent for the retinal detachment results. Gariano et al suggested that elevated leptin levels in the setting of 
retinal detachment were likely related to retinal ischemia; however, methodologic differences between the present study and that of Gariano et al may have led to these different results. Specific discrepancies include our use of an ELISA technique for determining leptin levels (compared with a radioimmunoassay) and our duplication of all leptin tissue level determinations (vs a single evaluation). The present study's significantly higher vitreous leptin levels in the presence of PDR are likely related to the use of the ELISA procedure. We believe our finding of normal vitreous leptin levels in PVR and rhegmatogenous RD is a more understandable result. Hernandez et al's ${ }^{10}$ study failed to show an elevated vitreous level in 25 consecutive patients undergoing vitrectomy surgery for proliferative diabetic retinopathy; however, their study excluded subjects with vitreous haemorrhage. All of our vitreous samples that were positive for leptin had significant, recent vitreous haemorrhages. Our two samples from diabetic subjects that demonstrated normal leptin levels did not have recent vitreous bleeds (one subject had a sub-hyaloid haemorrhage and the other a had chronic ochre haemorrhage).

Our data suggest that, in eyes with PDR, leptin reaches the vitreous (a) via the extravasation of blood from active retinal neovascularization and (b) by the expression of leptin by fibroblasts ${ }^{11}$ within diabetic neovascular membranes (unpublished observations). Once in the vitreous, leptin is a likely contributor to progressive fibrovascular proliferation. As a result, strategies targeting leptin, or its receptor, may offer potential therapies for ocular angiogenesis in the setting of proliferative diabetic retinopathy.

\section{Acknowledgements}

The study was funded in part by a grant from Canadian Institutes of Health Research MOP 42389.

\section{References}

1 Caldwell RB, Bartoli M, Behzadian MA, El-Remessy AE, Al-Shabrawey M, Platt DH et al. Vascular endothelial growth factor and diabetic retinopathy: pathophysiological mechanisms and treatment perspectives. Diabetes Metab Res Rev 2003; 19(6): 442-455.

2 Erb MH, Sioulis CE, Kuppermann BD, Osann K, Wong CG. Differential retinal angiogenic response to sustained intravitreal release of VEGF and bFGF in different pigmented rabbit breeds. Curr Ey eRes 2002; 24(4): 245-252.

3 Castellon R, Hamdi HK, Sacerio I, Aoki AM, Kenney MC, Ljubimov AV. Effects of angiogenic growth factor combinations on retinal endothelial cells. Exp Eye Ees 2002; 74(4): 523-535.

4 Elner SG, Elner VM, Jaffe GJ, Stuart A, Kunkel SL, Strieter RM. Cytokines in proliferative diabetic retinopathy and proliferative vitreoretinopathy. Curr Eye Res 1995; 14(11): 1045-1053.

5 Kojima S, Yamada T, Tamai M. Quantitative analysis of interleukin-6 in vitreous from patients with proliferative vitreoretinal diseases. Jpn J Ophthalmol 2001; 45(1): 40-45.

6 Sierra-Honingmann MR, Nath AK, Murakami C, GarciaCardeña, Papapetropoulos A, Sessa WC et al. Biological action of leptin as an angiogenic factor. Science 1998; 281: 1683-1686.

7 Gariano RF, Nath AK, D'Amico DJ, Lee T, SierraHonigmann MR. Elevation of leptin in diabetic retinopathy and retinal detachment. Invest Ophthalmol Vis Sci 2000; 41: 3576-3581.

8 Gokhan U, Metin O, Zeki B, Vedat E, Necati B, Ozdermir IC. Is leptin associated with diabetic retinopathy. Diabetes Care 2000; 23: 373-384.

9 Gokhan U, Metin O, Alper S, Can K, Tayfun E, Necati B et al. Is leptin associated with hypertensive retinopathy? J Clin Endocrinol Metab 2000; 85: 683-687.

10 Hernandez C, Lecube A, Castellanos JM, Segura RM, Garat $\mathrm{M}$, Garcia-Arumi J et al. Intravitreous leptin concentrations in patients with proliferative diabetic retinopathy. Retina 2004; 24(1): 30-35.

11 Glasow A, Kiess W, Anderegg U, Berthold A, Bottner A, Kratzsch J. Expression of leptin $(\mathrm{Ob})$ and leptin receptor $(\mathrm{Ob}-\mathrm{R})$ in human fibroblasts: regulation of leptin secretion by insulin. J Clin Endocrinol Metab 2001; 86(9): 4472-4479. 